\title{
THE POLYMORPHISM C9681T IN THE PROLACTIN RECEPTOR GENE AND FUNCTIONAL TRAITS OF DAIRY CATTLE
}

\section{POLIMORFIZM C9681T W GENIE RECEPTORA PROLAKTYNY A CECHY FUNKCJONALNE BYDŁA MLECZNEGO}

Department of Genetics and Animal Breeding, West Pomeranian University of Technology, Szczecin, Poland

${ }^{1}$ Department of Ruminant Science, West Pomeranian University of Technology, Szczecin, Poland

\begin{abstract}
Streszczenie. $W$ pracy analizowano polimorfizm typu pojedyncze podstawienie nukleotydowe C9681T (A536V), zlokalizowany w eksonie 10 genu kodującego receptor prolaktyny. Badania prowadzono w stadzie bydła rasy polskiej holsztyńsko-fryzyjskiej odmiany czarno-białej. Identyfikacja genotypów poszczególnych osobników prowadzona była przy użyciu PCR-RFLP. W pracy stwierdzono następującą frekwencję alleli polimorfizmu C9681T: C-0,81 i T-0,19. Genotypu TT w analizie nie zidentyfikowano. Analiza statystyczna wykazała, że krowy o genotypie CC charakteryzowały się wyższą wydajnością mleka niż krowy o genotypie heterozygotycznym, a te $z$ kolei cechowały się dłuższym okresem międzywycieleniowym. Otrzymane wyniki nie zostały potwierdzone statystycznie.
\end{abstract}

Key words: PRLR gene, polymorphism, fertility, dairy cattle.

Słowa kluczowe: PRLR, polimorfizm, płodność, krowy mleczne.

\section{INTRODUCTION}

Prolactin (PRL) is a peptide hormone secreted mainly by the anterior pituitary gland, which is involved in the initiation and maintenance of lactation in mammals. This hormone also affects, among others, the synthesis of the major components of milk, affecting all the steps of the milk proteins genes expression: transcription, stability of the mRNA, translation and post-translational modification of proteins. (Freeman et al. 2000; Kelly et al. 2000). More recently it has been shown that prolactin affects metabolic functions and reproduction by kinase pathway JAK2/STAT(Janus kinase 2/ signal transducer and activator of transcription) - Bachelot and Binart (2007).

Biological activity of prolactin depends on the combination of this hormone with specific receptor that belongs to the superfamily of class I cytokine receptors, and these are characterized by their ability to activate JAK2 and STAT (Goffin et al. 1999).

Corresponding author - Adres do korespondencji: Ewa Czerniawska-Piątkowska, Department of Ruminant Science, West Pomeranian University of Technology, Szczecin, Doktora Judyma 10, 71-460 Szczecin, Poland, e-mail: ewa.czerniawska-piatkowska@zut.edu.pl 
The gene encoding prolactin receptor in cattle has been mapped on chromosome 20, specifically in the region of $20 \mathrm{q} 17$, is composed of 10 exons separated by introns from which the coding exons include exons 3-10 (Brym et al. 2005; Lü et al. 2011).

In recent times, many authors focus on the analysis of polymorphism in the prolactin receptor gene in relation to the characteristics of breeding pigs and sheep (van Rens et al. 2003; Tomas et al. 2006; Chu et al. 2007; Barreras-Serano et al. 2009). However, the state of knowledge on the effects of PRLR gene on reproductive traits of cattle is still limited.

Therefore, studies were undertaken to investigate the relationship between A536V polymorphism in the prolactin receptor gene and selected reproductive features of cattle of Polish Holstein-Friesian breed of black and white variety.

\section{MATERIAL AND METHODS}

The study included 150 cows of Polish Holstein-Friesian breed of black and white variety held in the territory of West Pomerania. All the animals were kept in the captive system under similar environmental conditions. Cows were fed in a standard manner, and in the spring and summer period they used the pasture. Milk yield of the herd was assessed using A4 method. From each animal one collected a complete peripheral blood sample to vacuum tubes. DNA extraction was carried out using a DNA isolation kit according to the isolation protocol attached to the kit.

The genotypes of individual animals were determined using PCR-RFLP method. One analyzed SNP polymorphism in exon 10. The polymorphism consists in transition of cytosine to thymine at position 9681 of the nucleotide sequence from the base at position +1 (GenBank AJ9663356, rs524620576), which in turn leads to a change of the alanine amino acids to valine at position 536 of the peptide (A536V). To amplify a fragment of prolactin receptor gene of 305 base pairs in length, one used the following primers pair elaborated by Lü et al. (2011). The PCR products were evaluated by electrophoresis using agarose electrophoresis kit. Electrophoresis was performed in $2 \%$ agarose gel containing ethidium bromide in the buffer TBE at a voltage of $90 \mathrm{~V}$, in the presence of the pUC19/Mspl. DNA template. The next step was the digestion of the obtained amplification products with the Hhal restriction enzyme. The resulting restriction fragments were separated in $2 \%$ agarose gels with ethidium bromide in the buffer TBE at a voltage of $90 \mathrm{~V}$, in the presence of the pUC19/Mspl. DNA template. The PCR products and restriction fragments were visualized and archived using a set for documentation and analysis of electrophoresis gels. Genotyping results obtained were subjected to statistical analysis. In order to characterize the genetic structure of the population, one carried out the following calculations: frequency of occurrence of C9681T genotype and the frequency of specific alleles.

In the next stage of the study one analyzed the relationship between genotypes and the following traits of reproductive usefulness: age at first calving (AFC) and the calving interval (CI). Data on usefulness of cows were obtained on the basis of breeding documents of the farm kept by the Polish Federation of Cattle Breeders and Dairy Farmers (PFHBiPM). Statistical analysis of the relationship between C9681T polymorphism and milk performance traits and selected reproductive parameters were performed using Statistica 12.5 PL program. One calculated the mean values $(\bar{x})$ and standard deviation (SD) and conducted one-factor analysis of variance using Duncan's multiple range test. 


\section{RESULTS}

The conducted statistical analysis of the results of genotyping in the studied cattle herd of Polish Holstein-Friesian breed and black-and-white variety indicates that the homozygous CC genotype occurred most frequently, and heterozygous genotype was less frequent. In the case of alleles frequency it was found that allele $\mathrm{C}$ is much more frequent than the T allele (Table 1).

Table 1. Frequency of genotypes and allele of the polymorphism C9681T

Tabela 1. Frekwencja genotypów i alleli polimorfizmu C9681T

\begin{tabular}{lcccc}
\hline & \multicolumn{2}{c}{ Genotypes - Genotypy } & \multicolumn{2}{c}{ Alleles - Allele } \\
\cline { 2 - 4 } & CC & CT & C & T \\
\hline $\begin{array}{l}\text { Frequency } \\
\text { Frekwencja }\end{array}$ & 0.61 & 0.39 & 0.81 & 0.19 \\
\hline $\begin{array}{l}\text { Numer } \\
\text { Liczebność }\end{array}$ & 92 & 58 & & \\
\hline
\end{tabular}

In Table 2 are presented mean values and standard deviation for milk yield and functional traits for the C9681T genotypes. Cows of homozygous CC genotype were characterized by higher milk yield as compared to heterozygous genotype cows. Age at first calving of cows for both genotypes was equal and amounted to 850 days. A longer calving interval was characteristic for animals with CT genotype (482 days). Its extension suggests a reproduction disorders of cows and the shortening reduces the effectiveness of conception rate and milk production in lactating. In the conducted study there was no significant phenotypic correlations between first calving age and the length of calving interval and polymorphic C9681T variants.

Table 2. Mean values and standard deviation for milk yield and functional traits for the C9681T genotypes

Tabela 2. Średnie wartości i odchylenie standardowe dla wydajności mleka i cech funkcjonalnych dla genotypów C9681T

\begin{tabular}{lcccc}
\hline $\begin{array}{c}\text { Genotype } \\
\text { Genotyp }\end{array}$ & $\mathrm{n}$ & $\begin{array}{c}\text { Milk yield } \\
\text { Wydajność mleka } \\
{[\mathrm{kg}]}\end{array}$ & $\begin{array}{c}\text { AFC } \\
\text { WPW } \\
\text { [dni - days] }\end{array}$ & $\begin{array}{c}\mathrm{Cl} \\
\text { OMW } \\
\text { [dni }- \text { days] }\end{array}$ \\
\hline CT & 58 & $9074 \pm 874.27$ & $850 \pm 10.21$ & $482 \pm 91.20$ \\
CC & 92 & $9317 \pm 876.37$ & $850 \pm 094.97$ & $460 \pm 70.97$ \\
\hline
\end{tabular}

$\mathrm{n}$ - numbers - liczebność, AFC - age at first calving - WPW - wiek pierwszego wycielenia, $\mathrm{Cl}$ - calving interval OMW - okres międzywycieleniowy.

\section{DISCUSSION}

The marker-assisted selection of dairy cattle, the prolactin and its receptor are proposed as potential genes aspiring to features such as milk performance traits due to the broad spectrum of action of prolactin.

C9681T polymorphism was considered by Lü et al. (2011) in relation to Chinese Holstein cattle and in this study one also did not identify homozygous TT genotype, but demonstrated different frequency distribution of genotypes - the most frequent was the heterozygous 
genotype (0.724), while the frequency of $C$ allele was similar (0.724). The divergence in the distribution of particular genotypes can result from various breeds which were subjected to own research and Lü et al. (2011) studies and not a very large number of both examined herds of cows.

The C9681T polymorphism located in exon 10 of the encoding gene of the prolactin receptor has so far been tested in relation to the dairy traits, by Lü et al. (2011), where it was shown that homozygous $\mathrm{CC}$ genotype cows were characterized by a statistically significantly higher milk yield than cows of CT genotype. TT genotype in this study, as in own study, has not been identified. In the same study one also noted that individuals with heterozygous genotype were characterized by a higher content of fat and protein in milk than the cows with CC genotype, in this case the differences were not statistically significant.

Polymorphism in the gene encoding the prolactin receptor has so far been tested for breeding characteristics of pigs and sheep (van Rens et al. 2003; Tomas et al. 2006; Chu et al. 2007; Barreras-Serrano et al. 2009). Oprządek (2007) investigated PRL-HD polymorphism with respect to the breeding value of calving age, the calving interval and the number of insemination on effective breeding of cows of Polish red and white variety. In their study she found no effect of locus PRL/Rsal polymorphism on the tested functional features.

Various studies indicate the effect of the PRLR gene on the rate of ovulation in pigs which has an impact on the rate of metabolism and vitality of newborn piglets (Tomas et al. 2006). In addition, it was also shown that this gene is associated with the condition of the ovaries, uterus and placenta (van Rens et al. 2003). However, in other studies, it was found that a polymorphism in the prolactin receptor gene affects the size of parity in pigs (Barreras-Serano et al. 2009). In sheep, it has been shown that polymorphism in the PRLR affects fertility and size of parity (Chu et al. 2007).

\section{CONCLUSIONS}

The conducted statistical analysis of the results of genotyping in the studied herd of Polish Holstein-Friesian breed and black-and-white variety indicates that the most frequently occurring genotype was homozygous CC genotype, the heterozygous genotype was less frequent. often. Age at first calving for both cows genotypes was equal and amounted to 850 days. A longer calving interval was characteristic for animals with CT genotype (482 days). Its extension suggests the occurrence of disturbances in reproduction of cows, while shortening reduces the effectiveness of the conception rate and milk production in lactating. There was no effect of C9681T polymorphism on milk yield and analyzed functional features. No studies have been conducted so far on cows of this breed. To be able to use the results of conducted research in dairy cows breeding, one should continue to study the effect of various genotypes of C9681T polymorphism in the PRLR gene on milk traits and functional traits in different breeds of cattle and more numerous herds.

\section{REFERENCES}

Bachelot A., Binart N. 2007. Reproductive role of prolactin. Reproduction 133, 361-369.

Barreras-Serrano A., Herrera-Haro J.G., Hori-Oshima S., Gutiérrez-Espinosa A., Ortega-Cerrilla M.E., Pérez-Pérez J., Lemus-Flores C., Kinejara-Espinosa A.L., González-Aranguré A., Soto-Avila J.G. 2009. Prolactin receptor (PRLR) gen polymorphism and associations with reproductive traits in pigs. J. Anim. Veter. Adv. 8, 469-475. 
Brym P., Kamiński S., Wójcik E. 2005. Polymorphism within the bovine prolactin receptor gene (PRLR). Anim. Sci. Pap. Rep. 23, 61-66.

Chu M.X., Mu Y.L., Fang L., Ye S.C., Sun S.H. 2007. Prolactin receptor as a candidate gene for prolificacy of small tail han sheep. Anim. Biotech. 18,65-73.

Freeman M.E., Kanyicska B., Lerant A., Nagay G. 2000. Prolactin: structure, function, and regulation secretion. Physiol. Rev. 80, 1523-1631.

Goffin V., Binart N., Clement-Lacroix P., Bouchard B., Bole-Feysot C., Edery M., Lucas B.K., Touraine P., Pezet A., Maaskant R., Pichard C., Helloco C., Baran N., Favre H., Bernichtein S., Allamando A., Ormandy C., Kelly P.A. 1999. From the molecular biology of prolactin and its receptor to the lessons learned from knockout mice models. Genet. Anal., Biomol. Eng. 15, 189-201.

Kelly P.A., Bachelot A., Kedzia C., Henninghausen L., Ormandy C.J., Kopchick J.J., Binart N. 2002. The role of prolactin and growth hormone in mammary gland development. Mol. Cell. Endocrinol. 197, 127-131.

Lü A., Hu X. Chen H., Dong Y., Zhang Y., Wang X. 2011. Novel SNPs of the bovine PRLR gene associated with milk production traits. Biochem. Genet. 49, 177-189.

Oprządek J. 2007. Charakterystyka genetyczna populacji polskiego bydła rasy czerwono-białej $z$ uwzględnieniem polimorfizmu wybranych loci [Genetic characteristics of the Polish Red-and-White cattle population including the polymorphism of selected loci]. Rozpr. Inst. Genet. Hod. Zwierz. Jastrzębiec 18. [in Polish]

Tomas A., Casellas J., Ramirez O., Munoz G., Noguera J.L., Sanchez A. 2006. High amino acid variation in the intracellular domain of the pig prolactin receptor (PRLR) and its relation to ovulation rate and piglet survival traits. J. Anim. Sci. 84,1991-1998.

Van Rens B.T.T.M., Evans G.J., Lende T. van der. 2003. Components of litter size in gilts with different prolactin receptor genotypes. Theriogenology 59, 915-926.

Abstract. The study analyzed the polymorphism of single nucleotide substitution C9681T (A536V) type, located in exon 10 of prolactin receptor gene. The study was conducted in a herd of cattle of Polish Holstein-Friesian breed of black and white variety. Identification of genotypes of individuals was performed using PCR-RFLP. The study stated the following frequency of C9681T polymorphism alleles: C-0.81 and T- 0.19. TT genotype was not identified in the analysis. Statistical analysis showed that the CC genotype cows were characterized by higher milk yield as compared with cows with the heterozygous genotype, and the latter were characterized by a longer calving interval. The results were not confirmed statistically. 
